\title{
Arkadiusz Borowiec
}

\section{Kluczowe czynniki dostępu mikroprzedsiębiorstw do rynku zielonych zamówień publicznych w Polsce ${ }^{1}$}

Kody JEL: K00, K22, K23

Słowa kluczowe: mikroprzedsiębiorstwa, metodyka myślenia sieciowego, zielone zamówienia publiczne

Streszczenie. W niniejszym artykule, wykorzystując wyniki badań własnych oraz metodykę myślenia sieciowego autorstwa P. Gomeza, G. Probsta oraz H. Ulricha, podjęto próbę wyodrębnienia oraz diagnozy kluczowych czynników wpływających na dostęp mikroprzedsiębiorstw do rynku zielonych zamówień publicznych w Polsce. $\mathrm{W}$ celu prawidłowej ich identyfikacji $\mathrm{W}$ artykule przyjęto punkt widzenia mikroprzedsiębiorcy.

\section{Wprowadzenie}

Zielone zamówienia publiczne (GPP) definiuje się jako proces, w którym władze publiczne starają się pozyskiwać dostawy, usługi i roboty budowlane, wykazujące się zredukowanym wpływem na środowisko naturalne w całym cyklu ich życia w przeciwieństwie do pozyskiwania dostaw, usług i robót budowlanych o tym samym przeznaczeniu - kupowanych $\mathrm{w}$ alterna-

\footnotetext{
${ }^{1}$ Niniejszy tytuł nawiązuje do problematyki podjętej w ramach konferencji Mikrofirma 2013 oraz Mikrofirma 2014 wskazującej na kluczowe czynniki dostępu mikroprzedsiębiorstw do rynku zamówień publicznych oraz rynku partnerstwa publiczno-prywatnego w Polsce.
} 
tywnym przypadku (Komunikat KE, 2008). Ten rodzaj zamówień publicznych jest instrumentem dobrowolnie stosowanym w krajach Unii Europejskiej, a władze publiczne poszczególnych państw same decydują o poziomie jego implementacji. Celem zielonych zamówień publicznych jest osiągnięcie w możliwie jak najszerszym zakresie uwzględniania aspektów środowiskowych w procedurach przetargowych.

Zielone zamówienia publiczne mogą być także jednym z głównych źródeł rozwoju innowacji, zapewniając przemysłowi dostarczenie realnych zachęt dla rozwoju ekologicznych produktów i usług, szczególnie w tych sektorach, w których nabywcy publiczni mają duży udział w rynku (budownictwo, ochrona zdrowia, transport publiczny). W przypadku wzięcia pod uwagę całego cyklu życia produktu ten rodzaj zamówień może generować także dla władz publicznych wymierne oszczędności finansowe.

Komisja Europejska zidentyfikowała dziesięć sektorów priorytetowych wdrażania ekologicznych zamówień publicznych. Należą do nich: budownictwo, usługi gastronomiczne i cateringowe, transport i usługi transportowe, energetyka, urządzenia biurowe i komputery, odzież, uniformy i inne wyroby włókiennicze, papier i usługi drukarskie, meble, środki czyszczące i usługi sprzątania, a także sprzęt wykorzystywany w służbie zdrowia. Wyboru tych sektorów dokonano na podstawie oferowanych możliwości poprawy stanu środowiska naturalnego, wpływu na stronę podażową, wydatków finansowych, istnienia kryteriów służących do ich wyboru, wydajności ekonomicznej, dostępności odpowiednich produktów, a także przykładu dla konsumentów prywatnych i korporacyjnych (Komunikat KE, 2008).

Pomimo zalet zielonych zamówień publicznych zakres ich wykorzystania w Polsce jest znacznie mniejszy niż w większości krajów Unii Europejskiej. Obecnie w Polsce kryteria środowiskowe stosuje się tylko w nieco ponad $10 \%$ zamówień publicznych ${ }^{2}$. Niestety brakuje danych odnośnie do wykorzystania tego rodzaju zamówień wśród najmniejszych przedsiębiorstw, aczkolwiek lista priorytetowych sektorów wyodrębnionych przez Komisję Europejską pozwala przypuszczać, że mają one duże szanse i możliwości, aby skutecznie wpisać się w rynek zielonych zamówień publicznych.

Celem niniejszego artykułu jest wyodrębnienie oraz przeanalizowanie czynników warunkujących szerszy dostęp mikroprzedsiębiorców do rynku zielonych zamówień publicznych. W związku z tym posłużono się wynikami badań własnych i prowadzonymi przez innych badaczy, a także wykorzystano metodykę myślenia sieciowego opartą na teorii systemów. W związku

\footnotetext{
${ }^{2}$ http://www.brief.pl/artykul,1167,po_co_nam_zielone_zamowienia_publiczne.html (24.11.2015).
} 
$\mathrm{z}$ tym, że istotą metodyki jest spojrzenie na problem z różnych punktów widzenia, analizy czynników dokonano w grupie studentów studiów podyplomowych Zamówienia publiczne i partnerstwo publiczno-prywatne ${ }^{3}$. Aby prawidłowo zidentyfikować kluczowe czynniki ułatwiające dostęp do rynku zielonych zamówień publicznych, przyjęto punkt widzenia mikroprzedsiębiorców. Z punktu widzenia problematyki podjętej w niniejszym artykule $\mathrm{w}$ analizie pominięto aspekt czasu związany $\mathrm{z}$ oddziaływaniem czynników w sieci. Aby zawęzić obszar analizy, na potrzeby niniejszego artykułu przyjęto, że liczba czynników w sieci nie przekroczy piętnastu.

\section{Analiza stanu istniejącego}

Rynek zamówień publicznych stanowi jeden z największych rynków w skali całej polskiej gospodarki narodowej stanowiąc system powiązań wielu elementów, za pomocą których może on ciągle się rozwijać. Jednym $\mathrm{z}$ jego podsystemów jest rynek zielonych zamówień publicznych, co determinuje wybór metodyki myślenia sieciowego, związanej z poszukiwaniem kluczowych czynników dostępu mikroprzedsiębiorstw do tego rynku i ma swój rodowód w teorii systemów.

Metodyka myślenia sieciowego składa się z sześciu wzajemnie ze sobą powiązanych faz, które nie mają charakteru sekwencyjnego, dzięki czemu możliwy jest powrót do wcześniej zrealizowanej fazy lub przechodzenie przez nią kilkakrotnie. Do faz tych należą: ustalenie celów i modelowanie sytuacji problemowej, analiza oddziaływań, ujęcie i interpretacja możliwości zmian sytuacji, objaśnienie możliwości kierowania, planowanie strategii i działań, wprowadzenie rozwiązania problemu w życie (Ulrich, Probst, 1990).

Po realizacji pierwszej fazy, a więc ustaleniu celu badania oraz określeniu sytuacji problemowej należy stworzyć sieć powiązań pomiędzy czynnikami wpływającymi na zdefiniowany problem oraz przeprowadzić analizę ich wzajemnych oddziaływań. Bardzo istotny jest też wybór czynnika znajdującego się w centrum sieci, którą należy budować w stosunku do tego czynnika. Ze względu na problematykę niniejszego artykułu zdecydowano, że czynnikiem tym będzie dostęp mikroprzedsiębiorstw do rynku zielonych zamówień publicznych. Po dyskusji w grupie ekspertów przyjęto, że będą z nim związane następujące elementy sieci: popyt, Unia Europejska, przy-

\footnotetext{
${ }^{3}$ Grupa ta składała się z 17 osób, wśród których znajdowali się zarówno Zamawiający, jak i Wykonawcy reprezentujący bardzo zróżnicowane sektory, np. budowlany, odzieżowy, meblarski, transportowy. W grupie znajdowały się także osoby niezwiązane z rynkiem zamówień publicznych (m.in. audytorzy, handlowcy), dzięki czemu zgodnie z zasadami metodyki uzyskano różne punkty widzenia na rozpatrywany problem.
} 
jazne prawo, branża, innowacje i ekoinnowacje, kapitał ludzki, podatki, koszty pracy, szara strefa, certyfikaty i atesty, mentalność zamawiających, technologie środowiskowe, konkurencyjność przedsiębiorstw, polityka firmy. Sieć zależności między wymienionymi czynnikami przedstawiono na rysunku 1.

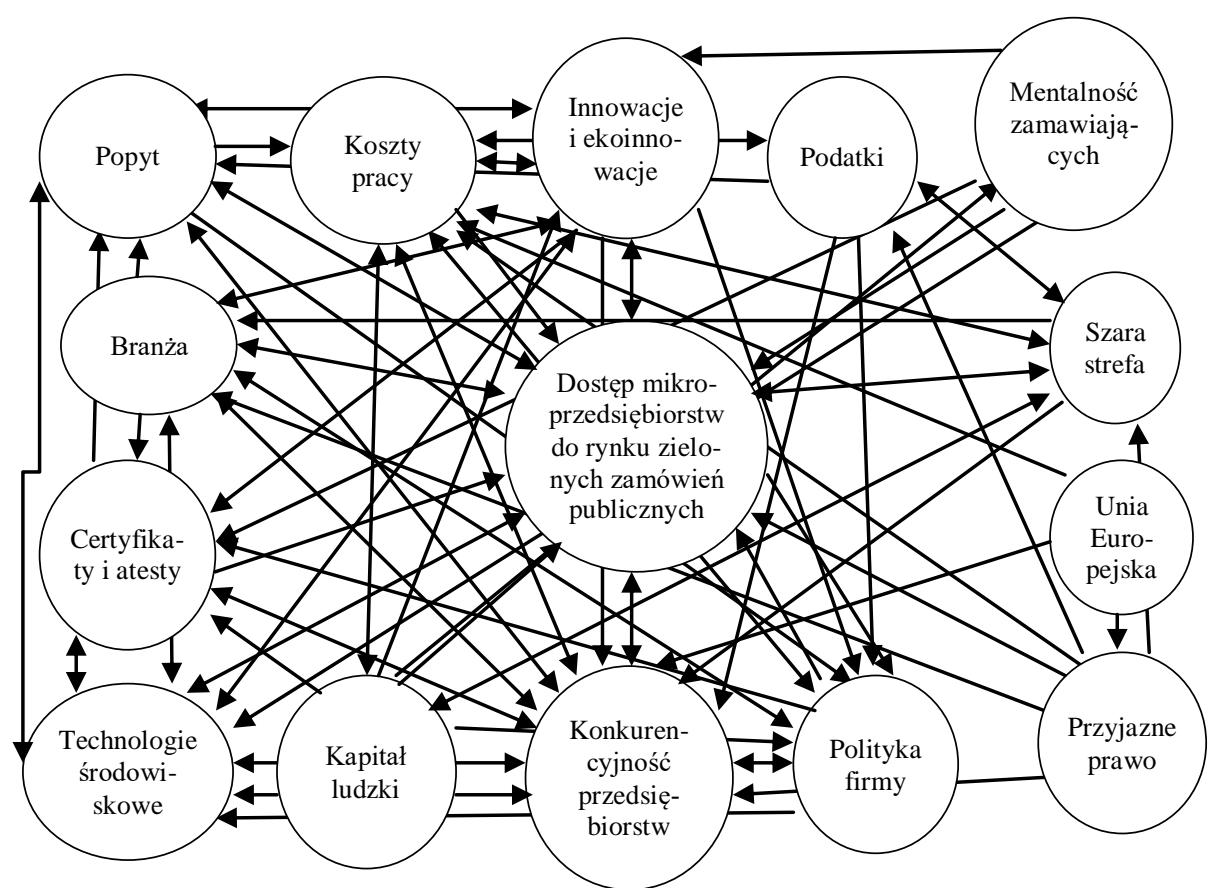

Rysunek 1. Sieć zależności wpływających na dostęp mikroprzedsiębiorstw do rynku zielonych zamówień publicznych

Źródło: opracowanie własne.

Analiza oddziaływań między wymienionymi na rysunku 1 czynnikami obejmować powinna ich rodzaj oraz intensywność. Jeśli chodzi o rodzaj to odpowiadają mu kierunki strzałek wskazujące na oddziaływania jednokierunkowe oraz dwukierunkowe. Intensywność natomiast przedstawiono w tabeli 1, czyli tzw. macierzy intensywności. Przyjęto w niej, że intensywności 0 odpowiada brak oddziaływania, natomiast 3 - bardzo silne oddziaływanie. Zarówno analiza rodzaju, jak i intensywności oddziaływania przeprowadzona została w gronie 17 ekspertów uczestniczących przy budowie sieci.

Po zsumowaniu aktywności i pasywności czynników należy określić, które z grona czynników przedstawionych w sieci należą do: 
- aktywnych, czyli takich, które bardzo mocno wpływają na inne czynniki same jednak praktycznie nie podlegając wpływom,

- krytycznych, czyli takich, które mocno wpływają na inne czynniki, natomiast same również podlegają podobnym wpływom,

- pasywnych, czyli takich, które słabo oddziałują na inne czynniki, niemniej jednak same podlegają silnym wpływom,

- leniwych, czyli takich, które zarówno słabo oddziałują na inne czynniki jak i same podlegają słabym wpływom.

Tabela 1

Macierz wpływów

\begin{tabular}{|c|c|c|c|c|c|c|c|c|c|c|c|c|c|c|c|c|c|}
\hline Lp & Nazwa czynnika & 1. & 2. & 3. & 4. & 5. & 6. & 7. & 8. & 9. & 10. & 11. & 12. & 13. & 14. & 15. & $\begin{array}{c}\text { Suma } \\
\text { A }\end{array}$ \\
\hline 1. & $\begin{array}{c}\text { Dostęp mikro- } \\
\text { firm do GPP }\end{array}$ & $\mathrm{X}$ & 1 & 0 & 1 & 0 & 0 & 1 & 1 & 0 & 0 & 1 & 0 & 2 & 2 & 0 & 9 \\
\hline 2. & Popyt & 2 & $\mathrm{X}$ & 1 & 2 & 0 & 0 & 0 & 0 & 0 & 0 & 2 & 0 & 2 & 3 & 0 & 12 \\
\hline 3. & Koszty pracy & 2 & 0 & $\mathrm{X}$ & 2 & 2 & 0 & 0 & 3 & 0 & 0 & 0 & 2 & 1 & 2 & 0 & 14 \\
\hline 4. & $\begin{array}{c}\text { Innowacje } \\
\text { i koinnowacje }\end{array}$ & 2 & 2 & 1 & $\mathrm{X}$ & 0 & 0 & 2 & 0 & 2 & 0 & 2 & 0 & 3 & 1 & 0 & 15 \\
\hline 5. & Podatki & 0 & 2 & 3 & 0 & $\mathrm{X}$ & 0 & 0 & 3 & 0 & 0 & 0 & 0 & 2 & 1 & 0 & 11 \\
\hline 6. & $\begin{array}{c}\text { Mentalność } \\
\text { zamawiających }\end{array}$ & 3 & 0 & 0 & 3 & 0 & $\mathrm{X}$ & 0 & 0 & 2 & 0 & 1 & 0 & 0 & 0 & 0 & 9 \\
\hline 7. & Branża & 2 & 1 & 0 & 2 & 0 & 0 & $\mathrm{X}$ & 0 & 2 & 0 & 1 & 0 & 2 & 1 & 0 & 11 \\
\hline 8. & Szara strefa & 1 & 0 & 2 & 0 & 3 & 0 & 1 & $\mathrm{X}$ & 0 & 0 & 0 & 2 & 2 & 0 & 0 & 11 \\
\hline 9. & $\begin{array}{c}\text { Certyfikaty } \\
\text { i atesty }\end{array}$ & 2 & 1 & 0 & 0 & 0 & 0 & 0 & 0 & $\mathrm{X}$ & 0 & 1 & 0 & 2 & 0 & 0 & 6 \\
\hline 10 & $\begin{array}{c}\text { Unia Europej- } \\
\text { ska }\end{array}$ & 0 & 0 & 1 & 0 & 0 & 0 & 0 & 0 & 0 & $\mathrm{X}$ & 0 & 0 & 2 & 0 & 1 & 4 \\
\hline 11 & $\begin{array}{c}\text { Technologie } \\
\text { środowiskowe }\end{array}$ & 1 & 1 & 0 & 1 & 0 & 0 & 1 & 0 & 2 & 0 & $\mathrm{X}$ & 0 & 1 & 0 & 0 & 7 \\
\hline 12. & Kapitał ludzki & 1 & 0 & 2 & 1 & 0 & 1 & 0 & 2 & 1 & 0 & 2 & $\mathrm{X}$ & 2 & 2 & 0 & 14 \\
\hline 13 & $\begin{array}{c}\text { Konkurencyj- } \\
\text { ność przeds. }\end{array}$ & 1 & 2 & 1 & 0 & 0 & 0 & 1 & 0 & 2 & 0 & 1 & 0 & $\mathrm{X}$ & 2 & 0 & 10 \\
\hline 14. & Polityka firmy & 2 & 0 & 1 & 0 & 0 & 0 & 1 & 0 & 1 & 0 & 1 & 0 & 2 & $\mathrm{X}$ & 0 & 8 \\
\hline 15 & $\begin{array}{c}\text { Przyjazne } \\
\text { prawo }\end{array}$ & 3 & 0 & 2 & 0 & 3 & 0 & 2 & 2 & 0 & 0 & 0 & 0 & 2 & 0 & $\mathrm{X}$ & 14 \\
\hline & Suma P & 22 & 10 & 14 & 12 & 8 & 1 & 9 & 11 & 12 & 0 & 12 & 4 & 25 & 14 & 1 & \\
\hline
\end{tabular}

Źródło: opracowanie własne.

Przedstawiona w tabeli 1 macierz wpływów jest punktem wyjścia dla opracowania mapy intensywności, która jednoznacznie pozwala przypisać wymienione w niej czynniki do jednej z czterech opisanych grup. Pozwala jednocześnie zidentyfikować, które czynniki pełnić mogą kluczową rolę z punktu widzenia dostępu mikroprzedsiębiorstw do rynku zielonych zamó- 
wień publicznych. Tworząc mapę intensywności niezwykle ważne jest poprowadzenie granicy podziału między czynnikami. W niniejszej analizie przyjęto, że linie podziału będą przebiegać w miejscach, które powstają w wyniku podzielenia maksymalnej wartości A oraz P przez 2. Uzyskane $\mathrm{W}$ ten sposób wartości to $\mathrm{A}=7,5$ oraz $\mathrm{P}=12,5$. Mapę intensywności przedstawiono na rysunku 2.

$\mathrm{Z}$ mapy intensywności wynika, że kluczowymi czynnikami dostępu mikroprzedsiębiorstw do rynku zielonych zamówień publicznych są: mentalność zamawiających (6), szara strefa (8), branża (7), podatki (5), popyt (2), kapitał ludzki (12), przyjazne prawo (15), innowacje i ekoinnowacje (4). Warto na tym etapie określić, które $\mathrm{z}$ nich są kierowalne przez właściciela mikrofirmy, a które pozostają poza jego możliwościami. Czynnikami kierowalnymi są innowacje i ekoinnowacje oraz kapitał ludzki.

To właśnie na te dwa czynniki mikroprzedsiębiorcy powinni zwrócić szczególną uwagę $\mathrm{w}$ procesie poszukiwania determinant dostępu do rynku zamówień publicznych. Kapitał ludzki daje przedsiębiorstwu możliwość skutecznego konkurowania oraz zapewnia możliwości wygrywania ekologicznych przetargów, natomiast innowacje i ekoinnowacje (Carley, Spapens, $2010)^{4}$ powodują, że firma staje się bardziej konkurencyjna i potrafi dopasować się do kryteriów prośrodowiskowych generowanych przez zamawiających.

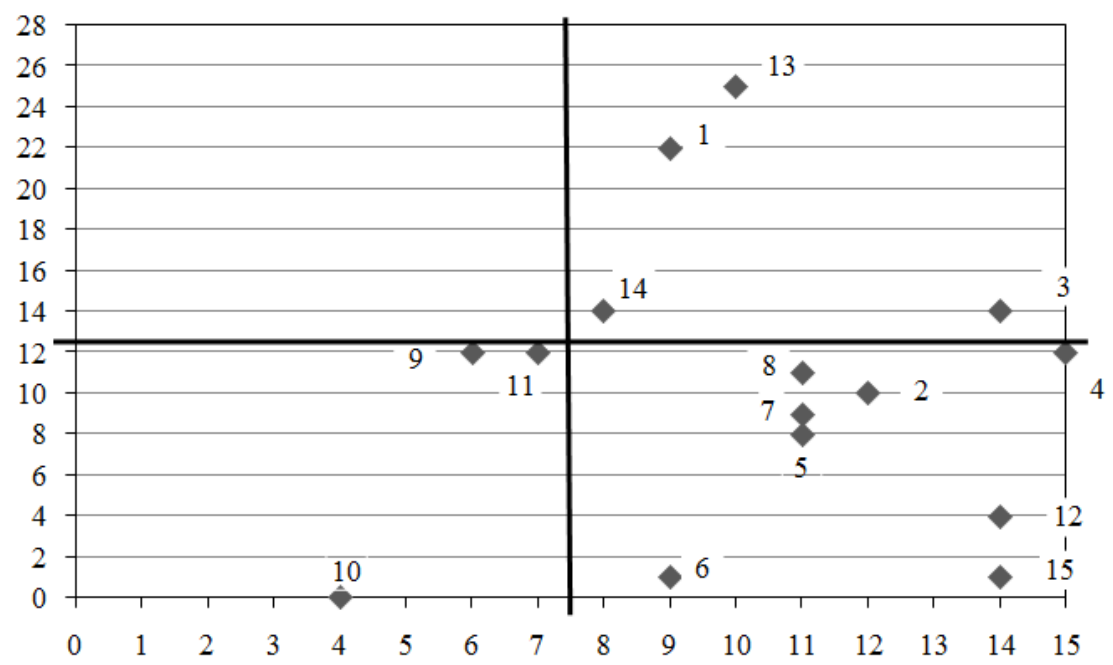

Rysunek 2. Mapa intensywności

Źródło: opracowanie własne.

${ }^{4}$ P. James definiuje ekoinnnowacje jako nowy produkt lub proces, który zapewnia wartość dla klienta i dla biznesu oraz jednocześnie znacząco obniża negatywny wpływ na środowisko. 
Z mapy intensywności wynika także duża rola państwa w ułatwianiu dostępu do rynku zielonych zamówień publicznych najmniejszym podmiotom. Warto również zauważyć, że z czynników krytycznych, znajdujących się na mapie intensywności, sterowalnym o dość istotnym znaczeniu są koszty pracy (3). Czynnik ten trudno jednak poddać gruntownej analizie, gdyż dotyczy bardzo złożonego problemu i jego zastosowanie może w równym stopniu wywołać pozytywne co negatywne skutki. Warto jednak wspomnieć, że oszczędzanie $\mathrm{w}$ związku $\mathrm{z}$ zatrudnianiem profesjonalnej i dobrze wykształconej kadry może doprowadzić do niekorzystnych zjawisk dotyczących przygotowywania i przeprowadzania postępowań przetargowych, w tym doprowadzić do występowania zjawisk korupcyjnych. Warto więc analizując koszty pracy w podmiocie udzielającym zamówień publicznych zachować szczególną ostrożność, ponieważ skutki wykorzystania tego czynnika mogą być trudne do przewidzenia.

Trzecia faza metodyki myślenia sieciowego zakłada konieczność przeprowadzenia interpretacji możliwości zmian sytuacji w odniesieniu do kluczowych czynników otrzymanych w poprzednich etapach. W tym celu warto wykorzystać metodę scenariuszową opartą na założeniu, że przyszłych zdarzeń nie da się przewidzieć ze stuprocentową pewnością, w związku z tym należy przewidzieć i opracować różne scenariusze rozwoju obecnej sytuacji (Gierszewska, Romanowska, 2004). Scenariusze optymistyczny, pesymistyczny i prawdopodobny przedstawiono w tabeli 2 .

Opisane scenariusze rozwoju pomagają lepiej zrozumieć istotę czynników wpływających na dostęp mikroprzedsiębiorstw do rynku zielonych zamówień publicznych.

W kolejnej fazie metodyki myślenia sieciowego należy objaśnić możliwość kierowania zmianą. Warto $\mathrm{w}$ tym celu zastosować model opisany przez G. Klimarczyka, M. Masadyńskiego oraz M. Wyrwicką (2009), w którym uwzględnia się czynniki sterowalne oraz niesterowalne przez decydenta, sprzężenia zwrotne i wyprzedzające oraz indykatory (lub wskaźniki wczesnego ostrzegania). Punktem odniesienia we wspomnianym modelu jest mikroprzedsiębiorstwo i jego dostęp do zielonych zamówień publicznych.

Model kierowania zmianą w celu zwiększania dostępu mikroprzedsiębiorstw do rynku zielonych zamówień publicznych przedstawiono na rysun$\mathrm{ku} 3$.

Szczególną rolę w modelu kierowania pełnią indykatory, gdyż pomagają decydentom podjąć odpowiednią strategię działania w sytuacji niepożądanych zmian. W przypadku przedstawionego modelu, ich spadek powinien 
skutkować podjęciem działań zaradczych, zmierzających do poprawy funkcjonowania całego systemu.

Tabela 2

Scenariusze rozwoju kluczowych czynników dostępu mikroprzedsiębiorstw do rynku zielonych zamówień publicznych w Polsce

\begin{tabular}{|c|c|c|c|}
\hline \multirow{2}{*}{ Czynniki } & \multicolumn{3}{|c|}{ Scenariusz } \\
\hline & optymistyczny & pesymistyczny & prawdopodobny \\
\hline 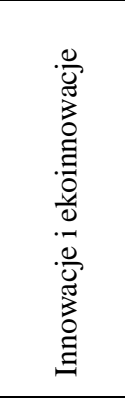 & $\begin{array}{l}\text { przez szerokie wykorzy- } \\
\text { stanie tzw. nowego podej- } \\
\text { ścia do zamówień pu- } \\
\text { blicznych opartego na } \\
\text { polityce innowacyjnej } \\
\text { zamawiającego, powsta- } \\
\text { wać będzie coraz więcej } \\
\text { proekologicznych orygi- } \\
\text { nalnych rozwiązań gene- } \\
\text { rowanych głównie przez } \\
\text { mikroprzedsiębiorstwa }\end{array}$ & $\begin{array}{l}\text { zamawiający wykorzy- } \\
\text { stując utarte schematy } \\
\text { działania nie będą } \\
\text { dopuszczali do przetar- } \\
\text { gów innowacyjnych } \\
\text { mikroprzedsiębiorstw i } \\
\text { nadal zamiast kryte- } \\
\text { rium innowacyjności } \\
\text { przyjmować będą do } \\
\text { oceny najniższą cenę }\end{array}$ & $\begin{array}{l}\text { mikroprzedsiębiorstwa, } \\
\text { jak dotychczas, tylko } \\
\text { sporadycznie będą } \\
\text { uczestniczyć w procedu- } \\
\text { rach przetargowych } \\
\text { dotyczących wykorzy- } \\
\text { stania innowacji i ekoin- } \\
\text { nowacji; większość } \\
\text { przetargów wygrywać } \\
\text { będą głównie duże } \\
\text { przedsiębiorstwa }\end{array}$ \\
\hline 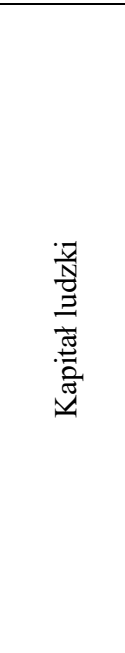 & $\begin{array}{l}\text { dzięki przemyślanej poli- } \\
\text { tyce kierownika komórki } \\
\text { ds. zamówień publicznych } \\
\text { zatrudniani będą pracow- } \\
\text { nicy z dużymi zasobami } \\
\text { wiedzy fachowej, do- } \\
\text { świadczenia i umiejętno- } \\
\text { ści, co przekładać się } \\
\text { będzie na bardzo sku- } \\
\text { teczną implementację } \\
\text { dyrektyw UE w świado- } \\
\text { mym stosowaniu przepi- } \\
\text { sów dotyczących zielo- } \\
\text { nych zamówień publicz- } \\
\text { nych i zlecania zamówień } \\
\text { mikroprzedsiębiorstwom }\end{array}$ & $\begin{array}{l}\text { do komórki zamówień } \\
\text { publicznych trafiać } \\
\text { będą pracownicy o } \\
\text { małym doświadczeniu } \\
\text { praktycznym i niewiel- } \\
\text { kiej wiedzy na temat } \\
\text { wykorzystania proce- } \\
\text { dur przetargowych w } \\
\text { inicjowaniu ,,zielonych } \\
\text { przetargów”, co spo- } \\
\text { woduje dalsze zmniej- } \\
\text { szanie odsetka proce- } \\
\text { dur, w których wyko- } \\
\text { rzystuje się proekolo- } \\
\text { giczne zamówienia i } \\
\text { udziału w przetargach } \\
\text { najmniejszych podmio- } \\
\text { tów }\end{array}$ & $\begin{array}{l}\text { pracownicy odpowie- } \\
\text { dzialni za przeprowa- } \\
\text { dzanie przetargów pu- } \\
\text { blicznych będą w dal- } \\
\text { szym ciągu kierować się } \\
\text { głównie standardami w } \\
\text { wyborze najkorzystniej- } \\
\text { szej oferty z rzadka } \\
\text { stosując dyrektywy } \\
\text { proekologicznych pro- } \\
\text { cedur; dzięki temu odse- } \\
\text { tek zielonych zamówień } \\
\text { publicznych będzie } \\
\text { bardzo powoli się } \\
\text { zwiększał }\end{array}$ \\
\hline
\end{tabular}

Źródło: opracowanie własne.

Z punktu widzenia wspomnianej poprawy należy zgodnie z metodyką myślenia sieciowego opracować propozycję działań. W związku z charakterem czynników znajdujących się w modelu działania, warto podzielić je na związane z postawą mikroprzedsiębiorstw i polityką państwa.

$\mathrm{Z}$ punktu widzenia mikroprzedsiębiorstwa obydwa czynniki sterowalne są ze sobą ściśle związane. Brak wiedzy, umiejętności i doświadczenia skutkuje najczęściej niestarannie przygotowaną ofertą, a co za tym idzie brakiem szans $\mathrm{w}$ postępowaniu dotyczącym przygotowania oferty na innowacyjny 
przedmiot zamówienia. Istniejąca praktyka w Polsce niestety w dużym stopniu problem ten pogłębia, gdyż najczęściej zamawiający oczekują od wykonawców potwierdzenia wysokich wymogów formalnych i dysponowania licznymi certyfikatami lub dokumentami potwierdzającymi wysokie kompetencje.

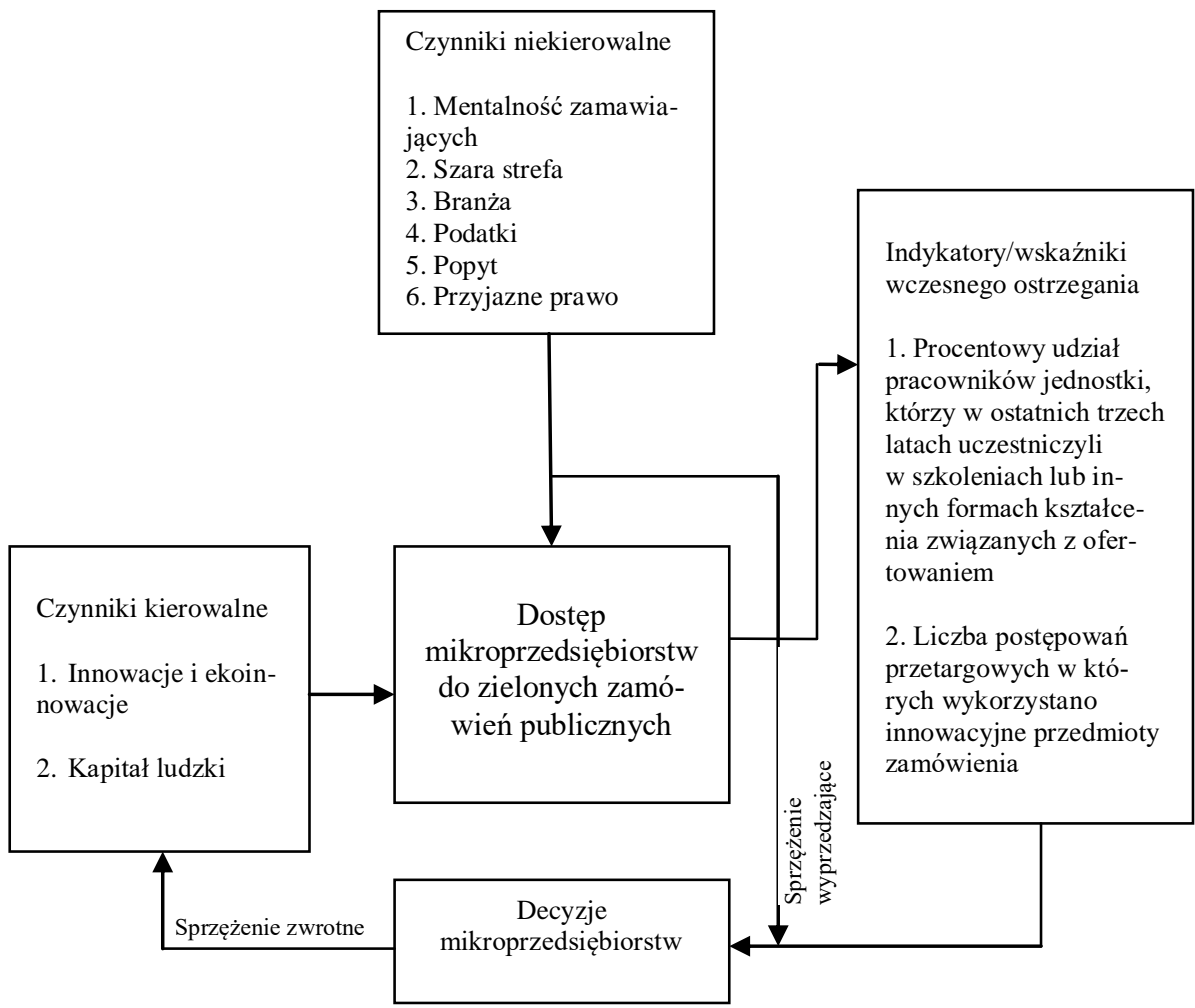

Rysunek 3. Model kierowania w celu zwiększania dostępu mikroprzedsiębiorstw do rynku zielonych zamówień publicznych

Źródło: opracowanie własne.

Ze strony państwa natomiast powinny być czynione działania zmierzające do wprowadzenia przejrzystych zasad prawa, opartych na implementacji dyrektyw unijnych w szerszym włączaniu mikroprzedsiębiorstw w procedury przetargowe oraz wykorzystywaniu w tych procedurach kryteriów innowacyjnych i jednocześnie prośrodowiskowych. Trudno jednak liczyć na spektakularne rezultaty tych działań, gdyż jak wskazują wyniki badań (Borowiec, 2013) zamawiający raczej sceptycznie wyrażają się na temat wpły- 
wu zielonych zamówień publicznych na kreowanie innowacyjnych rozwiązań (rys. 4).

Warto także przemyśleć, co wynika z mapy intensywności, wprowadzenie systemu zachęt opartego na preferencyjnej polityce podatkowej dla najmniejszych przedsiębiorców, oferujących zielony i jednocześnie innowacyjny przedmiot zamówienia oraz aktywnymi działaniami wpływać na likwidowanie szarej strefy.

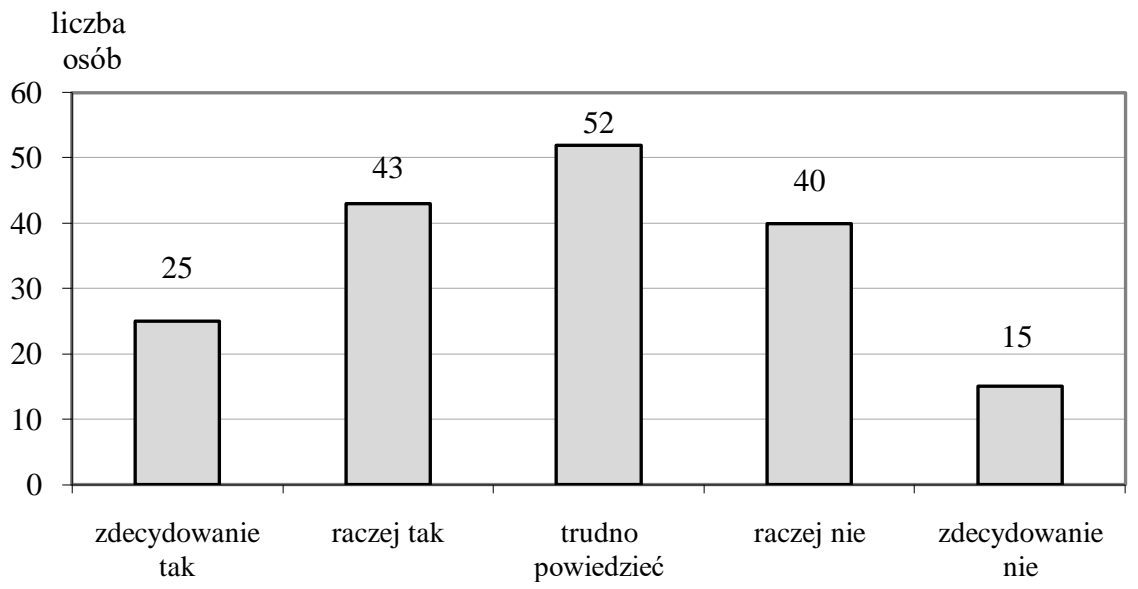

Rysunek 4. Wpływ zielonych zamówień publicznych na kreowanie popytu na innowacje w opinii zamawiających

Źródło: opracowanie własne.

Należy podkreślić, że nie we wszystkich branżach mikroprzedsiębiortwa mają możliwość uczestnictwa w postępowaniach przetargowych, w których wykorzystuje się kryteria proekologiczne. Tam gdzie przedmiot zamówienia jest standardowy i zamawiający wyznaczają sztywne kryteria, trudno na własną rękę wdrażać innowacje wykazujące się znikomym wpływem na środowisko naturalne.

Państwo w końcu powinno zgłaszać, wzorem innych krajów Unii Europejskiej, popyt na zielone zamówienia publiczne ${ }^{5}$, upowszechniając jednocześnie dobre praktyki w nich stosowane. Nie jest to na pewno zadanie przesadnie trudne, gdyż istnieje wiele opracowań przetłumaczonych na język polski, w których można znaleźć takie przykłady ${ }^{6}$.

\footnotetext{
${ }^{5}$ W takich krajach jak Belgia, Holandia, Dania i Szwecja zielone zamówienia stanowią 40$60 \%$ wszystkich postępowań.

${ }^{6}$ Przykładowo opracowania Polskiej Agencji Rozwoju Przedsiębiorczości.
} 


\section{Podsumowanie}

Jak wykazały wyniki przeprowadzonej analizy sieciowej kluczowymi czynnikami wspierającymi dostęp mikroprzedsiębiorców do rynku zielonych zamówień publicznych są kapitał ludzki oraz innowacje i ekoinnowacje w postępowaniach przetargowych.

W odniesieniu do kapitału ludzkiego warto zastanowić się nad podnoszeniem poziomu wiedzy i umiejętności osób zajmujących się zarówno udzielaniem zamówień publicznych, po stronie instytucji zamawiających, jak i wykonawców. Pomóc w tym może szeroki program szkoleń nastawiony na promowanie kryteriów proekologicznych i proinnowacyjnych, jak również przemyślana rekrutacja stawiająca kandydatom do pracy w systemie zamówień publicznych wysokie wymagania merytoryczne i formalne. Warto przy tym wspomnieć, że już od kilku lat istnieje zawód specjalisty ds. zamówień publicznych, o którego wprowadzenie już od lat 90 . XX wieku postulował Bank Światowy.

W zakresie innowacji oraz ekoinnowacji państwo powinno zintensyfikować swoje działania dotyczące promowania udziału mikroprzedsiębiorstw w przetargach publicznych, których przedmiotem są nowatorskie produkty i usługi o obniżonym wpływie na środowisko naturalne. Państwo powinno też pomyśleć nad stworzeniem przewodnika który zawierałby kompleksowe informacje na temat procedur, zasad, korzyści i trudności związanych $\mathrm{z}$ udzielaniem innowacyjnych zielonych zamówień publicznych. Powinien być utworzony katalog proinnowacyjnych kryteriów ekologicznych dla poszczególnych grup produktów, który byłby na bieżąco aktualizowany. Należy także promować innowacyjne rozwiązania proekologiczne stosowane wcześniej z powodzeniem w innych krajach.

\section{Bibliografia}

Borowiec, A. (2013). Zamówienia publiczne jako instrument kreowania popytu na innowacje. Poznań: Wydawnictwo Politechniki Poznańskiej.

Carley, M., Spapens, P. (2000). Dzielenie się światem. Białystok-Warszawa: Instytut na rzecz Ekorozwoju.

Gierszewska, G., Romanowska, M. (2004). Analiza strategiczna przedsiębiorstwa. Warszawa: PWE.

Klimarczyk, G., Masadyński, M., Wyrwicka, M. (2009). Zastosowanie analizy myślenia sieciowego do kierowania zmianą w firmie montażowej. Logistyka, 2.

Komunikat KE (2008). Zamówienia publiczne na rzecz poprawy stanu środowiska. COM 400.

Komunikat Komisji do Parlamentu Europejskiego, Rady, Europejskiego Komitetu Ekonomiczno-Społecznego oraz Komitetu Regionów. (2008). Zamówienia publiczne na rzecz poprawy stanu środowiska. Bruksela: KOM 400.

Ulrich, H., Probs,t G.J.B. (1990). Anleitung zum ganzheitlichen Denken und Handeln. Ein Brevier für Führungskräfte. Bern-Stuttgart: Verlag Paul Haupt. 
Krawcewicz M. (2015). Po co nam zielone zamówienia publiczne. Pobrane z:

http://www.brief.pl/artykul,1167,po_co_nam_zielone_zamowienia_publiczne.html (24.11.2015).

\section{Access Key Factors of Micro Market Green Public Procurement in Poland}

Keywords: microenterprises, thinking methodology Network, green public procurement

Summary. In this article, using the results of the study and the methodology of thinking network by P. Gomez, G. and H. Ulrich Probst attempt to isolate and diagnosis of key factors influencing the market access of micro green public procurement in Poland. In order to correctly identify them in the article assumes a micro point of view.

Translated by Arkadiusz Borowiec

\section{Cytowanie}

Borowiec, A. (2016). Kluczowe czynniki dostępu mikroprzedsiębiorstw do rynku zielonych zamówień publicznych w Polsce. Marketing i Zarządzanie, 2 (43), 11-22. 